\section{Basil Warwick Pett}

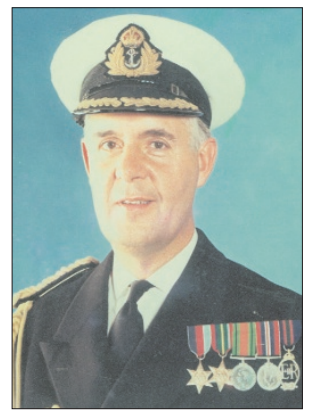

Basil Pett, who died on 16th October 2003, was born 10th November 1919. In the presence of a capacity congregation of family, friends and patients, his funeral took place on 27th October in the Chapel of Brighton College where he was educated and had maintained lifelong connections, which included membership of the Board of Governors and the presidency of the Old Brightonians.

When Basil left school in 1938, he entered Guy's Hospital Dental School which evacuated to Sherwood Park near Tunbridge Wells in September 1939 after the outbreak of the Second World War. At first, the somewhat boisterous activities of the students were not appreciated by the 'locals' but as the war progressed their energies were directed into more useful channels. In May 1940, the Home Guard was raised and Basil became an active member of the Sherwood Park Contingent. RD Emslie often described how Basil and he shared one rifle, as, eager to arrest enemy parachutists, they spent nights in a field listening to gunfire from the continent and to the nightingales of Kent.

On qualifying, Basil joined the Royal Navy as a Surgeon Lieutenant (D) RNVR and was appointed to the armed merchant cruiser, HMS Artifex, which then sailed to the East Indies. On leaving Artifex, he spent the remainder of the war at a Royal Naval Base on the remote South Pacific atoll, Manaus but got to Sydney for the celebrations.

On demobilisation, he combined teaching at Guy's with practice in Wimpole Street. In 1948 Basil married Margaret Miller and a family home in Hove was established, where they were to bring up their four sons. That year also saw the establishment of the peacetime RNVR which Basil promptly joined. Thus began a long and very

\section{David William Carmichael}

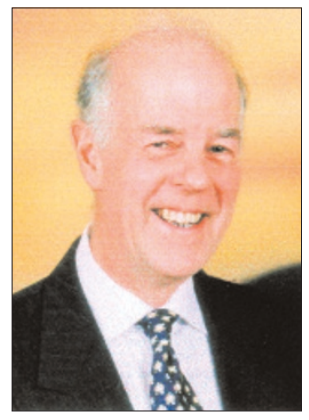

David died suddenly and without warning of a heart attack at his home on 2lst October 2003 at the youthful age of 59. David was born in Elgin and was always fiercely proud of his Scottish heritage. He was educated at the Elgin Academy and the Arnold School for Boys in Blackpool before entering the Charles Clifford Dental School in Sheffield.

After graduation in 1968, David worked for a short time in Blackpool before joining his uncle's practice in Downham Market. Within a few years he became a partner in this thriving firm. David married Juliet in 1971, and despite developing cancer, Juliet had a son Angus in 1975. Tragically, after a long illness, Juliet died in 1982. But with characteristic selflessness and enormous energy David set about raising Angus, running his busy practice and caring for those in his community. David was not just an organiser, he was a do-er; his support for dentistry in West Norfolk through many years service on the Norfolk LDC, and his contribution to the local community through his work for charity made him universally liked and respected. He cared passionately about the community in which he lived, and was an active member of a host of local organisations and charities.

With time, David's parental commitments gradually diminished and he married Katherine in 1994. A new chapter in David's life

\section{...his sense of humour was legendary. He was a magnificent host and enjoyed nothing more than a good party.}

happy association with HMS President, The London Division of the Royal Naval Reserve, culminating in his promotion to Surgeon Captain (D) and his appointment, when head of the RNR Dental Branch, as Honorary Dental Surgeon to Her Majesty the Queen. .

In 1950, Basil joined Robert Cutler, Gordon Hancock and Warren Harvey at 8 Lower Sloane Street. He was to spend the main part of his working life there playing his part as it became almost certainly the largest private dental practice in London.

Basil had, however, at one time considered the Bar, so when he was persuaded to become a JP in Brighton, his partners reluctantly but amicably agreed to his premature retirement from the London practice to take up his Magisterial post and to start a part time dental practice in Hove which he was to run for many years. In due course he also became a Tax Commissioner as well as Chairman of the local Gaming and Betting board. He was an active member of the Hove Club and for some years was its chairman.

As a raconteur Basil always displayed a light touch and his sense of humour was legendary. He was a magnificent host and enjoyed nothing more than a good party. He was a great family man and there are many stories around of the tremendous camping holidays in the south of France he and 'Margie' went on with the 'boys' and friends.

To his widow, Margie, their four sons and to their grandchildren, Basil's many friends and colleagues will wish to extend their deepest sympathy.

M. N. Naylor and H. K. Kemp

\section{...there is no doubt that, amongst the} \section{many people that he served from all walks} \section{of life, this 'caring' profession of ours has}

\section{never had a greater ambassador.}

opened up, with fresh interests and social activities that they both could share. But his commitment to the community remained high and in 2000 he trained and became a valued member of the Samaritans. Although he would never mention it, he could often be called upon to man their telephones into the early hours of the morning and then with little sleep he would work a full clinical day. Over the last couple of years David and Katherine had been busy planning for their retirement together. Not a sedate relaxing one, but one crammed full of action and purpose, for David could never sit still for long. Sadly this is not to be. We would like to add our condolences to the hundreds of messages of sympathy already received by Katherine and Angus from the people of Downham Market and West Norfolk.

At first glance David's career as a humble general practitioner was unremarkable; but there is no doubt that, amongst the many people that he served from all walks of life, this 'caring' profession of ours has never had a greater ambassador. 